\title{
Financial management for sustainable administration and institution - building
}

\author{
Babatunde Joel Todowede \\ Lagos State University, Lagos, Nigeria
}

\section{ABSTRACT}

This paper, entitled "Financial Management for Sustainable Admini cration and honBuilding", seeks to demonstrate the possible application of sound financial gem -1mec "nic aes for the attainment of enduring employment relationships and sustainable ur rsis, vernanc It should be recognized that employment relationships in the university system uld be ver $\mathrm{mp} / \mathrm{x}$, involving often delicate diversities, several competing multilateral interests ar a a ion process. Consequently, positive university governance should leverage strategic finzn 1 ma ment approaches for the effective and efficient utilization of financial resources that vailable
their founding objectives.

Keywords: university governance; financial management nnagement; sustainable administration

\section{INTRODUCTION}

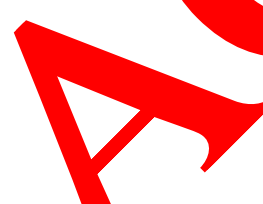

The structure of this pap is bry en into sme six broad parts for ease of presentation. Background information is nit on the societal role of education and social capacity building, while ome key a ciated underlying concepts (e.g. financial management, financial planning, fir an accounta (y) are explained. Thereafter, the issue of University funding and finances diso d. The variables that influence availability and management of university funds are rurther ela financial mo ageme for probable sustainable futures of university governance and institution-ou $q$. The $\mathrm{p}$ er concludes that the future of the university system, especially in an emeraing na such as Nigeria, lies in the embrace of best practices of university gove nany includ ound resource management, financial accountability and reporting as W. in tiatives an favour of strategic capacity building for symmetrical organization devel ent minn with the founding objectives.

\section{CONCEPTUAL FRAMEWORK OF THOUGHT}

Education is regarded as the singular most important instrument for holistic human development and the empowerment of citizens of any nation. The global perception agrees that for economic and social development to be derived effectively there is a need for advancement in, and application of knowledge (Adebayo, Oyenike and Adesoji, 2007). It is evident that illiteracy, or the lack of formal education, often constrains the logical process of human development in any nation. Given the importance of human capital and its harnessing for 
economic growth and sustainable development, widespread or free education is often a desirable ideal. However, depending on a country's economic endowment or financial resources, and the existence of various competing demands of public expenditure in the social sector, the financing of free or widespread education may be problematic and unaffordable or uneconomical. However, with the effective and efficient management of a nation's resources (human, material or physical/natural and financial), organizations therein, including universities, can very well sustain their existence, operations and growth.

Financial management means planning, organising, directing and controlling the financial activities such as procurement and utilization of funds of the Institution In other words, financial management is the management of the finances of a business/or anizat in order to achieve financial objectives. In general terms, it means applying gener nanageme principles to catalysing and sustaining the financial resources of the Institution.

Financial management includes (financial management, 2006);

- Financial planning and budgeting,

- Financial accounting,

- Financial analysis,

- Financial decision-making and

- Action.

Financial planning is about (financial manage nt, 2006);

- Making sure that the organization cônervive,

- Making sure the money is being spen tin mafficient way,

- Making sure that the money is being $s_{1}=$ to fy 11 the objectives of the organization,

- Being able to plan for the of the ganization in a realistic way.

Financial Accountabily: roanizations, whatever money is available for expenditure only is mean to be hel trust - on behalf of the affected community that is being served. The money is the person ossession of any organisation or person. Financial managers, therefore, ave ccount or the ways and means by which such money may be used as well as pancularly jus ruch usage with interest of public good.

Howey , finar ial accou rability can be broken down into two components (financial management, 06 .

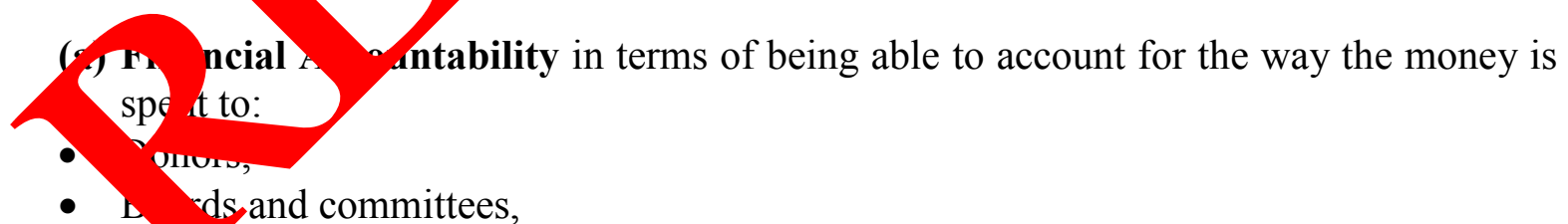

- b rds and committees,

- Me ibers, and

- The people whom the money is meant to benefit.

(b) Financial Responsibility, on the other hand, involves the following:

- Not taking on obligations the organization cannot meet,

- Paying staff and accounts on time, 
- Keeping proper records of the money that comes into the organization and goes out of the organization.

\section{1. Objectives of Financial management}

The primary purpose of financial management is to do with procurement, allocation and control of financial resources of a concern. The objectives of financial management specifically encompass the following (Ishola, 2008);

- To ensure regular and adequate supply of funds to the concern,

- To ensure optimum funds utilization. Once the funds are received should utilised in maximum possible way,

- To ensure safety on investment. This implied that funds shou be investo afe ventures so that adequate rate of return can be achieved,

- Overall control of the Institution's resources;

- Guidance to all departments in all financial matters, preparation and monitoring of their budgets;

- The Institution's accounting, reporting and intern control

- Maintaining the financial information system - Administering the pay-roll, loan and pension chemes;

- Arranging adequate insurance cover for the

- Ensuring that surplus funds are invested and $n$ versity's a sets;

\section{2. Financial resources available to the $U$ iver}

Financing higher education jo- igeria in the present is a crucial national problem. The political, social and economic factor which a currently having significant impact on the world economy, have necess.u th need to aiversify the resources of education funding, mainly because reliance 9 soure of revenue can inhibit educational growth. There are however some poss options o nancing higher education (Omolade, 2008):

- Fund from mer gov ment, popularly known as subvention,

- Tuitior and fues,

- Gifto, ante and E dowments,

- Investm income

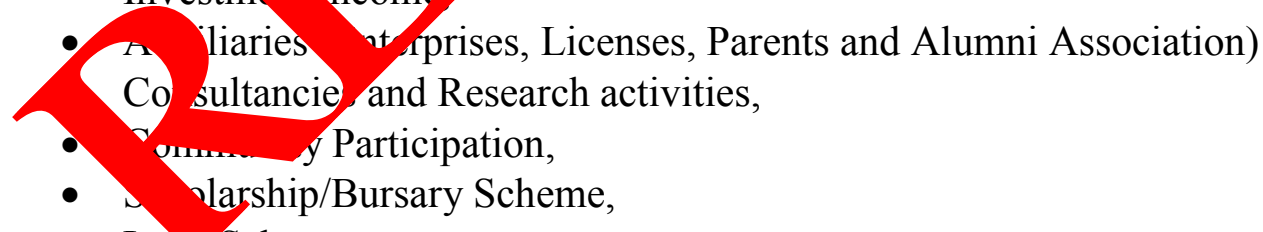

- Loà Scheme, etc.

The existing circumstances in the country and the attendant financial constraints have made education to suffer. Government is unable to ideally fund higher education effectively and efficiently due to lack of accurate baseline statistics the asymmetrical planning and prevalent economic crises. To sustain higher education in the country, all stakeholders must become involved in the financing, parents and guardian, the society in general, the private sector and non-governmental agencies. The education sector can only approach the optimal in 
provision and production when every stakeholder strives to do its part on the financing of higher education in Nigeria.

This paper, therefore, also isolates six critical factors that tend to influence new trends in the funding of Universities in Nigeria. These are (Erinosho, 2004):

- Massive expansion in University Education;

- Inability of the Country to finance this massive expansion, leading to the emergence of the private sector;

- The rationale for cost-sharing with parents and students;

- The public call for accountability and value for money;

- The emergence of foreign providers through the General Agreemen n Trade services (GATS);

- And, finally, the need for adjustment in Country funding to redy e wic aning

\section{3. Financial operations of Universities}

It should be noted that there have been major recent $\mathrm{ch}$ of universities in many countries. This change is as a rest of a vishing ublic resources with the resultant effect, in most cases, of financial con th with he university system. This situation has led to pressure from the governme $l$, and from withil the university system itself, for a diversification of sources of financial su ort to the Upiversity which must also be backed by effective resource management. From th bove obs rvations and scenarios, it is clear that the University can no longer rely solely on rorn. ent funding, if it is to remain financially healthy. New styles and mechani financiar management are necessary. There are six key characteristics of the financially h alth isity. These are (Akintayo, 2006):

- Short term solvency;

- Retention of reserves

- The effective mana on ren rong wabt;

- The effective m gement or estate;

- The stability ge te non-st re funding;

- Consisten orbudgo strategy with mission.

Never ess, Anit of differences between various institutions and systems, I believe that there are sh ndame dl principles that must be observed. They are (Akintayo, 2006):

Fin hcial sta 1ity, which should make a key contribution to academic success;

anagement, which is too important to be left to the Bursar or Director of

- A Servative approach to institutional spending at the top, which should constantly send a message in favour of lean management of organizational resources, as well as transparency and accountability throughout the institution;

- That, risks should be examined carefully but, when accepted, the instrument should be sufficient to ensure a successful outcome;

- Good financial management requires that, where financial targets are not met, action should be taken immediately;

- Financial monitoring by policy makers, rather than technicians, can make a significant impact on the management of an institution. 
It is necessary to state, at this juncture, that it is impossible to point to a 'right way' of managing University finance in general, because funding systems differ, and in particular, institutions differ. For example, managing the finances of a research university which has a significant grant income and major research facilities to maintain and, if it has a medical school, special relations with hospitals and state medical services or, if it has an agriculture or veterinary faculty, university farms to manage, are entirely different to managing the finances of a largely teaching university. This is not just a question of what the accounts of the two kinds of universities look like and the difference in the make-up of their income streams, but a matter of a different organization and structure.

It must be further noted that the most viable source of financing University the effective management of the university educational system and associa institutio Consequently, this paper also isolates six critical factors that tend to influence $\mathrm{h}$ trends the funding of universities. This can be done in the following ways (Obic amani, 20

- Rational allocation of cash funds;

- Management of cash reserves;

- Production of financial indicators;

- Better utilization of resources;

- Evaluation and auditing;

- Protection of funds from fraud.

In order to determine whether or not the fina of an organization are effectively managed, there is the need for financial ref ing. The une of financial reporting in the public sector, for example (where most unive stun the developing countries are located), is to give a formal record of the financial acti ti $s$ anc resources entrusted to it and provide information useful for decision $\mathrm{m}^{2}$ by (Edi ugbo, 2008):

- Indicating whether esc es lained and used in accordance with legally adopted budget;

- Indicating whe resources obtained and used in accordance with legal and contractual quiro nts, ineruding financial limits established by appropriate legislativ authorities,

- Provir ng inf rmation al out the resources, allocation and uses of financial resources;

- Provic ir ormat n about how the government or unit financed its activities and met itc cash iremeis;

Pi iding i Mation that is useful in evaluating governments or units' ability to fin nce its achivities and to meet its liabilities and commitments;

- ovrums information about financial condition of the government or unit and changes in

- Pro 1ding aggregate information useful in evaluating the governments or units performance in terms of service costs, efficiency and accomplishment.

\section{4. On the need for sustainable university administration and institution-building}

For a country, such as Nigeria, to get her quest for solid national development, there is the need to build sustainable and strong institutions. It must be noted at this juncture, that, if there has to be sustainable development in Nigerian universities, they have to be "adequately" funded. The financing of education should be the function of all the major stakeholders. This 
is because government alone cannot fund higher education. Inadequate funding of public universities has been identified as the prime cause of the problems of the universities (Ifakachukwu, 2009). There is need for strong institutions for service delivery, government efficiency, and strong policy and programme implementation. More importantly, there is the need to build capacity divorced from our individual, regional, religious and personal aggrandizement in order to encourage public and private sector sustenance.

It must be noted that, a country cannot grow or achieve much if she depends on individual genius, personality cult, and passion to run her public institutions.

The development of infrastructure, as well as maintenance and delivery of othor state services need viable and functional institutions. These institutions should be the iving towards the maintenance of the Country's dilapidated roads, outdated power in tructure a other conceivable public sector services.

It may be pertinent to further state, at this juncture, that governmen agencies $\mathrm{h}$ fai $\mathrm{ed}$ because they failed to build an enduring institutional structure. If th oover ent ho built sustainable institution or leveraged on strategic capacity build $\mathrm{gg}$, of th critical challenges that are being encountered in the country could have een min.

Further still, on Nigeria, substantial investments of the ato nealth ould be made in favour of the training and retraining of the national workfo e. Th because every nation's strength is in her work force. If an emerging nation scerr sigerlo yld develop a welldedicated and trained work force, a substantial part of the nation's de velopmental problems could have been solved.

\section{CONCLUSIONS}

By and large the importance ofeffective niversity governance cannot be under- stated, given the primacy of strategic edu ional a 1 knowledge management for the possible attainment of necessary econ ic g w wth and sustainable human development across the globe. The pursuit of the clu. uun.uitidimensional goals of sustainable university administration and stro ric capach building are also dependent on the extent to which institutional financia eso es are pru ently harnessed and managed.

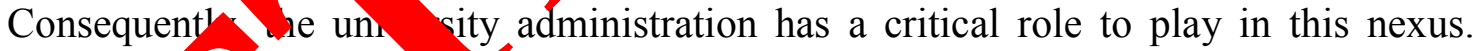
Indeed, succes al university ao Mistration in this $21^{\text {st }}$ century must leverage on the tenets of sound resoy s alle tion, utinization and financial management to catalyze processes of necessary capa buildin for balanced organization development and sustainable futures of the kno ge in

In c clusion, instrumentality of financial reporting, international best practices in stra ic $y$ matudministration and the necessary understanding of the harvestable pool of financ resources that is available to the global university system as well as various mechanis for putting these into usage for the promotion of industrial peace and organizational stability in the university system are all necessary ingredients for sound financial management for sustainable university administration and institution- building. 


\section{References}

[1] Abdu P. S (2003). "The Cost and Finance of Education in Nigeria" Education Today Quarterly, 10 (1); 12-16.

[2] Akintayo M. O. (2004) "Public Financing and the Problems of Access to University Education", International Journal of Literacy Education, 2; 1-23.

[3] Bloom B. S. Stability and Change in Human Characteristics, New York: Wiley 1964.

[4] Edukugbo E. (2008). "How $=\mathrm{N}=832.6$ billion on education in 8 years declined $\mathrm{i}$ terms". Vanguard Newspaper, Thursday, September 18, p. 51.

[5] Erinosho L. (2004). "Challenges in higher Education in Nigeria", a Convoca Lecture delivered at the University of Ado-Ekiti by the Executive Se retary, Social Science Academy, The Guardian Friday July 2, p. 46.

[6] Federal Ministry of Education (2007). "Community Accounta' ity 'Transp; ency Initiative for Universities", Abuja.

[7] Ishola R. A. (2008). "Optimising Output from Tertiary ducà al Instity rons Via Adequate Funding: A Lesson from Nigeria", Interna ral Rese Jurnal of Finance and Economics, 14.

[8] Obielumani I. (2006). "Universal Basic Educati (UBE) Wo kshop Requirements Projections for Ten years (2006-2015) in Delta S .. Journ ll of Education Research and Policies, 1(1); 86.

[9] Vanguard Newspaper, Thursday, $5^{\text {th }} \mathrm{Mar}$ h, $2,8$.

[10] UNESCO (1998). Higher Education in th Twenty first Century Vision and Actions, Paris UNESCO.

[11] World Bank (2002). Cans tip rumlodge Societies. New Challenges for Tertiary Education; Washing on, Wo Bank.

[12] Philip Usman A Or, Udens, Mternational Letters of Social and Humanistic Sciences 2 (20, 97-

[13] Abubaka Ami uoyi, In mational Letters of Social and Humanistic Sciences 3 (2014) 72 .

[14] Grema Mà Bukar Yohanna A. Timothy, International Letters of Social and

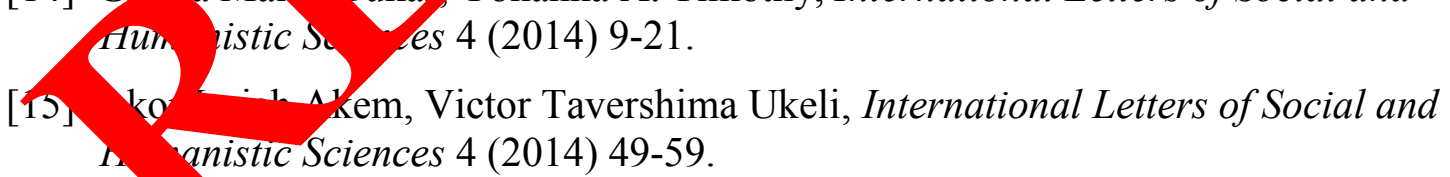

[16] Akpo ovwaire Samuel Mukoro, International Letters of Social and Humanistic Sciences 4 (2014) 60-70.

[17] Elizabeth Morenikeji Titilayo Adediran, Albert Oluyomi Kehinde, International Letters of Social and Humanistic Sciences 8(1) (2014) 66-75.

[18] S. A. Kazeem, K. Y. Balogun, International Letters of Social and Humanistic Sciences 8(2) (2014) 108-119. 
[19] Sanusi L. Sa'adatu, International Letters of Social and Humanistic Sciences 8(2) (2014) 140-147.

[20] Fowoyo Joseph Taiwo, International Letters of Social and Humanistic Sciences 8(3) (2014) 244-251.

[21] Adjekophori Bernard, International Letters of Social and Humanistic Sciences 12 (2014) 23-40.

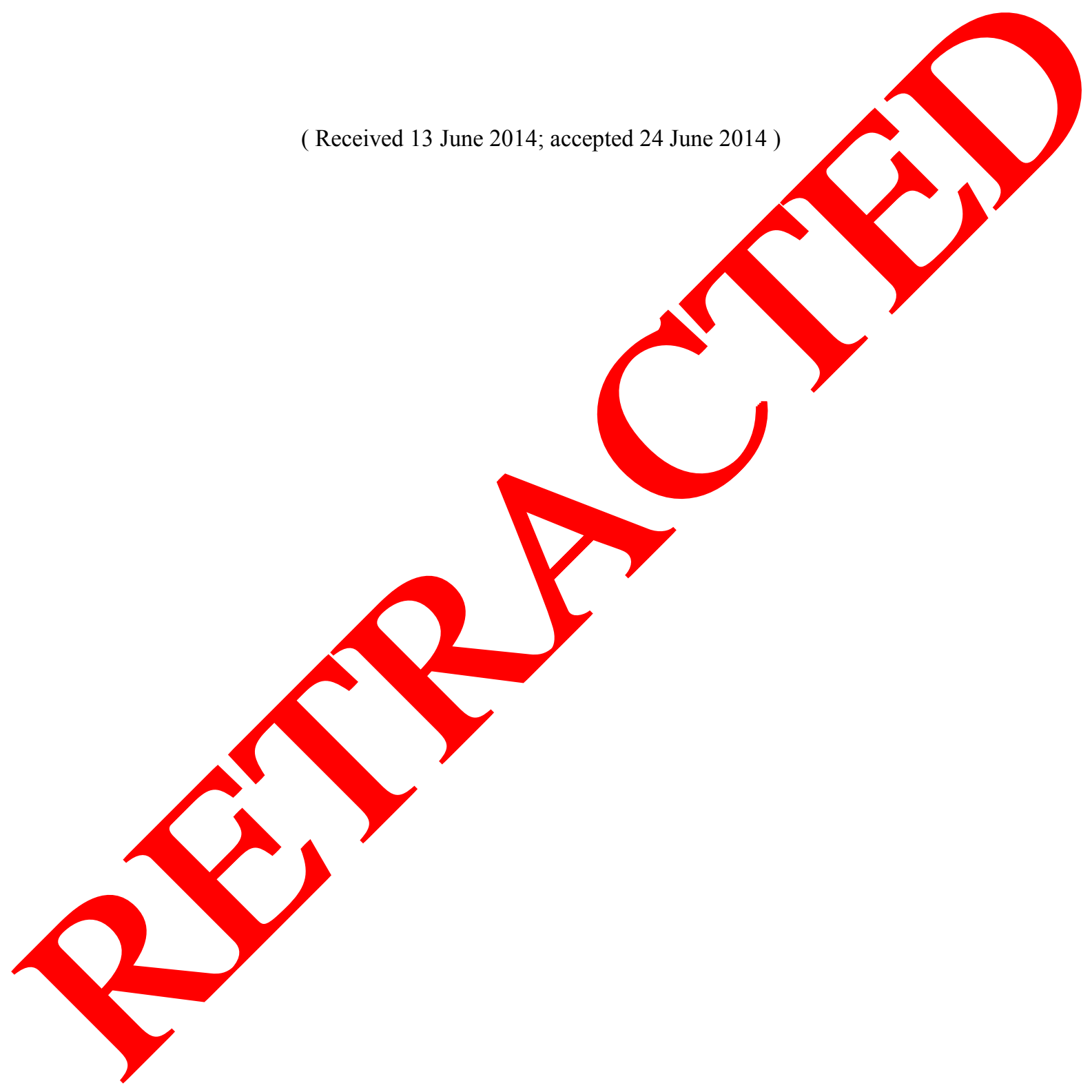

